\title{
The world is not enough: knowledge in question
}

\author{
J. Muller \\ Director of the Graduate School of Humanities \\ University of Cape Town \\ Cape Town, South Africa \\ E mail: jpm@humanities.uct.ac.za
}

\begin{abstract}
This article sounds a warning about threats to the continued good health of the Humanities globally, but especially in South Africa. It begins by examining the 'canonical position' of the knowledge enterprise and the academy, namely, that innovation can only be driven from within, not from without. This establishes the idea that a healthy academia requires 'necessary distance' from endogenous interests and agents, principally the state and the market, in order to survive. The article goes on to discuss contemporary threats to 'necessary distance', ranging from changes in the global model of university governance, to pressures for external attunement to external needs, the market, or to 'relevance', resulting in a new strategic regime of science. It next proceeds to review South African empirical work that assesses the degree to which the relevance imperative has had an impact in South Africa, and concludes that although curriculum change has by and large been patchy, that patterns in research and publishing show an alarming tendency to 'follow the money'. It is suggested that some disciplines are able to respond to relevance pressures whilst maintaining their disciplinary integrity more easily that others. One cluster of disciplines that is manifestly not thriving is the Humanities. An explanation for this incapacity is sought in the concept of knowledge structure, which is related to differential capacity for external attunement. The article concludes that, under the present strategic regime of science, the Humanities seem damned if they do and damned if they don't.
\end{abstract}

\section{THE WORLD AND THE UNIVERSITY}

Somewhere towards the end of the film The World is not Enough, one of the postCold War James Bond epics by Ian Fleming, the beautiful villainess Electra, having finally realised that James Bond is not to be bought off by her fabulous oilbased wealth, says sorrowfully to him, 'I would have given you the world'. James responds stoutly, 'The world is not enough'. 'Foolish sentiment', retorts sulky Electra. 'Family motto' replies James.

James Bond could well have been enunciating the family motto of knowledge work through the ages. Worldly prizes there may be, political recognition and princely livings not to be sneered at; but what drives the academic enterprise, so signifies the motto, is the work itself, the internal pleasures and epiphanies, the recognition amongst peers, the sheer delighting in playing with ideas, and producing genuinely novel knowledge. However cynical some of us may be today 
about this idealised picture of academic virtue, this is the canonical position on the desired relation between the university and the world, at least from the viewpoint of universities themselves and their professors. More roundly put, the canonical position, a broad church with many differing sects to be sure, asserts that higher education works best when it is allowed to steer its own ship according to its own lights. Let us call this the doctrine of endogeneity, or, the doctrine of internal selfpropulsion of knowledge.

Support of all kinds can and has been marshalled in support of the canonical position. The best known is the public position of university autonomy and academic freedom, as famously set forth in the doctrine of Lehrfreiheit in the 19th century German academies and, in this country, by T. B. Davie of the University of Cape Town in 1948, and as memorably affirmed by Jonathan Jansen in August 2004 to commemorate Davie and lament the waning cause of autonomy in South African higher education. As propounded by Davie, academic freedom entails the university's right to determine who shall be taught, who shall teach, what and how it shall be taught without regard to any criterion except academic merit. The same holds true for research. Academic freedom may be asserted against many external agents, but its traditional opponent is the state. This doctrine has been defended with lesser as well as greater degrees of naïveté. Nevertheless they all have in common the idea that when internal self-propulsion is breached or interfered with in any way, the academic project becomes thereby imperilled. ${ }^{1}$

Besides the autonomy argument, there are other arguments for the endogenous view that are worth considering. Robert Merton launched science studies in 1968 with an analysis of the five constitutive norms of the academic (or scientific) community. Of his five norms, all hotly contested by succeeding scholars, the most interesting and fundamental was the norm of communism, by which he meant the common ownership of intellectual goods. Merton did not mean that we all share the wealth of science in a trivial sense, collectivised intellectual property so to speak. He was pointing to a constitutive feature of science as being necessarily the outcome of collaboration and cooperation. Without extended informal cooperation and dialogue, science as we know it would be impossible. This collaboration signifies 'extension in both time and space', or as Bourdieu $(1997,23)$ has put it, the 'sovereign gaze' (that is, canonical knowledge) sees 'far in spatial but also in temporal terms'. Regarding time, the indebtedness of scholars to their forebears is encapsulated in the well-known aphorism attributed to Newton, 'if I have seen farther, it is by standing on the shoulders of giants'. Merton (1993) makes the point with great comic verve by showing that 'Newton's' aphorism had appeared at least 27 times in print before Newton ever used it, and could be traced back to Bernard of Chartres in 1126.

The point here is not that Newton had plagiarised the medieval texts, nor does it simply display the intertextuality so beloved of the post moderns; rather it shows that serious practitioners of knowledge have always understood their indebtedness to the community of scholars, to the communistic nature of their enterprise, hence 
the obligation to cite one's important forebears and also spatially, one's important contemporary peers. This injunction to recognition is embedded in the global practice, still current today despite its manifest shortcomings, of judging intellectual importance, worth and relative contribution in terms of citational density and peer review. Who we are, our standing as scholars, is judged through the eyes of our peers, a genuine, functioning Comintern of knowledge.

In a classic paper on the 'republic of science', Michael Polanyi (1962) points out the similarities between the ostensibly democratic dynamics of the market and 'communistic' science dynamics. The dynamics of both are created by the accretion of multiple independent initiatives mutually adjusting themselves at every successive stage stepwise towards a joint achievement. Such selfcoordination - by means of an invisible hand - is what is common (see also Lindblom and Cohen 1979). But the differences are more significant. Mutual adjustment in the market is on the basis of prices motivating agents to exercise economy in terms of money. Scientists, by contrast, are motivated by professional standards - plausibility, accuracy, importance, intrinsic interest, and above all, originality (see Polanyi 1962, 56-59).

In other words, and herein lies the uniqueness of the knowledge enterprise, the 'communism of new knowledge is a very individualistic kind of communitarianism' as Arthur Stinchcombe (nd, 20) puts it. But if it is not profits that drive the individuals that are regulated by these communistic professional norms, what then does drive them? It is the interplay of fame and vanity of a very particular sort: 'one gets prestige by being useful to others' (ibid, 18). Stinchcombe draws a conclusion that may be shocking to research managers: 'Broadly the way university reward systems are organised is that one gets a base salary for being oneself, then one can get infinite rewards in prestige if one actually does anything. And so we all do research, even though a simple-minded version of neoclassical economics would predict we would not?' (ibid).

This can be put more formally: 'The pursuit of the accumulation of knowledge is inseparably the quest for recognition and the desire to make a name for oneself' (Bourdieu 1997, 110). Indeed, as Stinchcombe drily comments, 'One of our great geniuses, Pierre Bourdieu for example, whose Distinction could easily be called the Das Kapital of socio-economics, welcomes the opportunity to speak to distinguished large audiences. He doesn't need any more distinction himself, but still seeks it eagerly. He gets that prestige reward by being useful to a great many scholars in a great many disciplines' (op. cit, 18). Incidentally, Stinchcombe is on this occasion, at an invited lecture in Amsterdam, making ironic reference to himself: 'When will colleagues reward one' he asks rhetorically 'for solid originality, freely given in Amsterdam after a very long night in a tourist class seat? . . . they will reward it only if it is useful to him or her' (ibid).

The paradox is certainly disarming: this vanity-driven communistic system is what makes the knowledge wheel turn, and what is, by the same token, as we might say, good for business. The net result is coordinated action in general, by 
virtue of subversion (that is, innovation) in particulars. Scientific or knowledge growth depends on principled subversion, on the precise enunciation of the unknown through loosely coordinated collective endeavour. 'Loosely coordinated' is here the nub of the matter.

Bourdieu (1997) has pithily described the symbiotic origins of the science system and of modern capitalism - in Renaissance Italy - in terms of the concept of the 'double break'. Modern capitalism established itself in distinction from other fields of human and social endeavour, and in so doing, established itself as a separate universe governed by its own rules - self-interested calculation, competition and exploitation. At the same time, the symbolic sciences establish themselves by suppressing the economic aspect of their symbolic actions and relations into the newly constituted economy. Hence they were able to constitute themselves as an autonomous sphere separate from the economic sphere and the sphere of practice, and in so doing, created the conditions, as Bourdieu says with typical Gallic pungency, for 'the invention of the universal' (ibid, 20), or as we more prosaically might say, for the spectacular growth of generalisable knowledge and culture in post-Enlightenment times.

Of course, one must readily concede that not only good things flowed from the autonomisation of the scholastic break and the professionalisation of the scholastic disposition into what we know today as the global university system. Society has had to endure all manner of scholastic hubris, as Bourdieu makes clear. Nor has it been without opposition from the philosophers, who ruled the medieval university after having wrested power from the priests. The point to be stressed here is that 'loose coupling', as the neo-institutionalists today call it (Drori et al. 2003) has been, and for the most part remains, the condition for the continued vibrancy and vitality of independent thought, innovation and knowledge growth.

Polanyi, exemplary endogenist that he is, concludes from his analysis that attempts to 'close couple' knowledge activity to external drivers like those of the state or of 'monied interests' (Roszack 1968, 8) that might seek to direct knowledge growth either for ethical (serving 'social' needs) or practical ('relevant') ends must therefore be futile, and concludes further that it is only possible to stop scientific trends, not to create or direct them: 'You can kill or mutilate the advance of science, you cannot shape it. For it can advance only by essentially unpredictable steps, pursuing problems of its own, and the practical benefit of these advances will be ... doubly unpredictable' (Polanyi 1962, 62). As far as unpredictability goes, Polanyi goes on to give the example of a BBC Brains Trust programme in January 1945 where he and Bertrand Russell had both denied any practical value to Einstein's theory of special relativity. A few months later, in August 1945, the atom bomb was dropped on Hiroshima and modern warfare changed forever.

Polanyi's analysis anticipates central insights of current economics of innovation. In this body of work we find the conundrum, already alluded to above, that normal novelty (first order learning) is relatively easily predictable and 
directable, but real or 'reconstructive' novelty (learning to learn) is in its essence uncertain: 'it is unpredictable and therefore cannot be selected by rational choice' (Nooteboom 1999, 128). In other words, real research novelty - true innovation cannot be rationally directed by policy on the supply side, or by users on the demand side. This is the classical picture, and it means that, classically, the core condition for the production of innovative knowledge is a relative 'necessary distance' both from supply-side direction or control, and from the demand-side tyranny of short term utility (Muller 2004).

This is the classical picture. But we do not live in classical times. In what follows, I will focus my comments on the forces which lead to changes in relation to the state, that is, to changes in governance; and on some of the forces which lead to changes in relation to the market. All of these, I will argue, work to collapse the relation of loose coupling, reduce the distance between universities and their external spheres in ways the universities have not experienced since the $18^{\text {th }}$ century, and place a question mark over whether necessary distance can still be preserved: that is, whether the conditions for universities to remain universities can still be preserved (or in Jansen's words, 'when does a university cease to exist?') As I will make clear, the answer is that parts of the university are thriving; parts are not. It is to the latter that I will finally turn.

\section{THE STATE, THE UNIVERSITY AND THE MARKET}

Many contemporary discussions on the vicissitudes of universities in global times invoke the spectre of increasing bureaucratic imposition on the business of academia. While this is certainly not wrong, it is easy here to conflate two things. The first is the state's changing mode of governance of universities; the second is the internal form of management of universities, sometimes called the 'new managerialism'. It is the first that the autonomy theorists dwell on, but it is the second that many academic commentators take to be the more insidious form of imposition, in the form of a steadily increasing encroachment on and control, some would even say 'theft', of precious academic time. The two are of course connected. I will consider each briefly, because that goes some way to explaining how the hubbub of disquiet has arisen, but also why they have not really elucidated what I regard as the primary fault line - the increasing threat to 'necessary distance'.

Contemporary analysts of 'public sector governance' seem agreed that, with the exception of the countries on the global periphery, what they call the 'traditional' (or Olsen's 'sovereign') governance model was, by the 1980s at the latest, said to be on its last legs. The main lineaments of the traditional model can be summarised as follows:

1. The civil service has to be apolitical, in other words 'neutrally competent'. In addition, politics and administration have to be seen as separate elements of governance. 
2. Public management has to be based on hierarchical principles and ruleboundedness.

3. The governmental organisations have to be permanent and stable.

4. The civil service should be institutionalised and governed as a corporate body.

5. The civil service should be strictly controlled and regulated in detail.

6. Finally, equality should be an important principle in governance, with respect to outcomes as well as organisation. (See Muller, Maassen and Cloete 2004).

In other words, the professional bureaucracy, formal rationality as described by Max Weber, was, by the 1980s, said to have outlived its usefulness as a generalisable model for university governance in the developed world, and various alternative models were replacing it - the dominant one being the market model associated forever with the name of Thatcher, but also variants of deregulated, flexible, and participative models (Peters 2001; Olsen 1988). In higher education, the clarion call of the time was, in van Vught's slogan, 'from state control to state steering' (Maassen and Van Vught 1988; Van Vught 1989; Maassen and Van Vught 1994). In one of those wonderful ironies that we can appreciate only in hindsight, we South Africans associated the 'traditional' model with apartheid, and, in the NCHE (1996) report and the subsequent White Paper (1997) embraced this thing called 'state steering', demanding the scrapping of an institution that we had never had (namely, efficient state regulation of universities) in the name of a governance abstraction that didn't properly exist anywhere, as subsequent less normatively-oriented scholarship was to make clear.

Absent from South African considerations at the time was an understanding of why the traditional model was giving way in the developed economies, and yes, it was partly because of globalisation, or rather, because of a set of changing structural global conditions - massification of higher education, the growth of private higher education, global competition for students, global research collaborations, and above all, the escalating costs and diversifying financing of what was rapidly becoming the business of higher education. The state could no longer run a uniform system, and experiments ensued that varied from Darwinian market forms to more flexibly steered modes where the state retained control over allocative accountability. All these variants presumed universities that could adapt in ways and at a speed that they had never been expected to before.

The above mentioned factors come into play very forcibly, as has been the case in South Africa in the post 1994 period, when institutions are faced with a sudden increase in demands for reform from the government and the society, and an unleashing of market forces, by both the government and a burgeoning local and global private higher education sector. Secondly, through a process of mimetic and normative isomorphism, institutional management's notions of 'successful' institutions has been exchanged, mimicked and adopted through professional networks that are responding, on the one hand to resource and legitimacy demands, 
and on the other hand to promoting their position (Cloete and Kulati 2003). Under these circumstances, the capacity to adapt managerially becomes a crucial resource variable.

It is of course to outside signals that universities must learn to adapt, and the better they get at it, the more external signals come to dictate core business inside the universities. This is the net effect of the dual governance/managerial revolution which, though it takes different forms and displays itself in different modular hybrids, seems to be re-arranging the way the global university system is operating. In short, the governance shift has cumulatively tutored universities into greater and greater success at external attunement. Much of it is without doubt necessary and useful. But when this tutored attunement begins to direct the core business of curriculum and research, when, in other words, the 'necessary distance' between the external world and the knowledge enterprise shrinks, then we must needs pay close attention.

\section{CURRICULUM AND RESEARCH: ADAPTATIONS TO OUTSIDE SIGNALS}

Let us look briefly at how this attunement has played out in practice, at how South African universities have responded to pressures for curriculum and research change since 1994. First, starting with curriculum. Recent studies on university curriculum change in South Africa are instructive in this regard (see Ensor 2000, 2001, 2004). Both the White Paper (1997) and the Higher Education Act (1997) exhorted universities to 'programmatise' their curricula, a measure seen by policy planners as necessary to break the grip of disciplinary majors on curricula and to promote greater interdisciplinarity and thereby achieve a greater 'relevance' in curricula widely perceived to be sunk in theoretical irrelevancies. Instead of uniform compliance, the result was a spectrum of institutional accommodations to programme policy, from high accommodation to low, from enthusiastic to reluctant. Insofar as the institutions had to make at least a token response to programmatisation because their statutory funding depended upon it, we could have expected some change in each institution. But the range and unevenness of change is noteworthy. Moreover, it is unclear whether the changes that were made were because of the policy, or because the universities were reading the need for change off some other market-based script. Indeed, the very varieties of change, and in one case, change in advance of the policy, makes it plausible that the proximate cause was something else over and above the policy (see Muller and Ogude 2002).

What then can we conclude about institutional responses to the policy of curriculum programme restructuring? From the evidence (see Ensor 2002) it seems that changing the curriculum in that particular way (towards interdisciplinary programmes) was resisted in various ways by many if not most of the institutions, such that attempts to break down disciplinary boundaries, especially with subjects that have robust disciplinary identities, from physics to history, resulted in internal 
disciplinary enclaves within the programmes, rather than in integrated programmes. In other words, the form of accommodation was observed, but not its substance.

Whereas curriculum restructuring towards 'relevance' was mandated by national policy documents, though relatively weakly enforced, university research towards greater 'relevance' to the developmental needs of society, though advocated in the White Paper of 1997, was more directly steered by changing the allocatory conditions for research awards to favour applied research. The results are ostensibly more positive. There is a dramatic shift away from 'basic' to 'applied' research, a 25\% shift over a five year period (Bawa and Mouton 2002, 315). The question is how we interpret this shift. Bawa and Mouton are inclined to see this as a response to both urgings on the part of government as well as a response to 'global pressures' for more applied research (Gibbons et al. 1994). What we can say is that there is more published applied research in South Africa than there used to be, relative to published basic research, which is certainly consonant with the policy. But why the two are consonant, or even if there is any relationship between them, is unclear. In fact, this may well be an artefact of something else altogether - like Internet publishing of basic research, a form of research not counted by the research referred to earlier.

To summarise so far: the research on curriculum restructuring concludes that the knowledge structure of a discipline shapes the form of accommodation to market and policy fashions, rather than vice versa; the research on research restructuring points to real changes in the publishing profile of the country's research output. In world terms, we are in a state of decline ('The overall picture of South Africa science, as measured by ISI data, is one of deterioration and decline', Pouris 2003, 426), having been overtaken in output terms by eight developing countries since 1995. We are worse off now than we were two decades ago. It would seem that the pluralisation and marketisation of research funding has left a distinct, and damaging, imprint on our capacity for knowledge innovation.

The optimal condition for innovation above can therefore be re-stated as: preserving 'necessary distance' especially from the user interface, when reputational advantage, professional standing, even survival, depend on an ever greater dependence on multiple sources of funding. The danger from this interface lies in the possibility of stunted research agendas, in the unintended consequence of 'crowding out' basic research (Glaser 2000), but it lies also in the danger of premature utilisation. All the user interface terms currently used to designate research applicability - 'relevance', 'responsiveness', 'context-of-application' research - embed the idea that the commissioning interface is necessarily the one the research results will be most applicable to. The economics of learning recognises that this is rarely so. ('Its early use may occur where it's fit with the prevailing architecture is feasible with a minimum of systemic changes rather than where it is most productive' (Nooteboom 1999, 138)). Many of science's most dramatic applications occur in a different time and space to that of the original 
discovery itself. ${ }^{2}$ The case of special relativity and nuclear fission is just one example. The peril of premature relevance is that eager commissioners at the user interface, anxious to show spending efficiency to their financial bosses, tend to go off half-cocked. The systemic consequence is a flaccid and malfunctioning innovation system.

The user interface is thus potentially now a greater danger to innovation than during the time of apartheid. What is to be done? The IDRC Report on the state of South Africa's science system contends that 'the thirty-year old idea of a "republic of science" (that is, scientific autonomy), in its simplest formulation, is still in fact a guide to the operation of South Africa's long-term S\&T policy' (IDRC 1993, 24), but this states the requirement - for greater distance from the user interface - rather than the means for achieving it. Certainly the clock is not going to be turned back to full state provision, the classical condition for full autonomy. What then is the contemporary condition for 'necessary distance' in research? In some quarters, the answer is seen as lying in the idea of 'strategic' research.

The National Commission on Higher Education Report (1996) had mentioned strategic research as one of four research types, the others being 'traditional', 'applications-driven', and 'participation-based' (see Mouton 2001, 6). Mouton goes on to trace the provenance of the idea of strategic research, showing that it is sometimes placed closer to applied, sometimes closer to basic research (basic research with a long term perspective). Rip $(1997,2001)$ extends this idea of what he calls the emerging regime of strategic science. In his view, scientists have begun to internalise the global pressure towards relevance and accountability, while holding on to the basic longer term trajectory of knowledge growth. In other words, scientists increasingly attend to global scientific horizons by means of framing them in terms of local issues (think local, act global): 'Strategic research combines relevance (to specific contexts, possibly local) and excellence (the advancement of science as such), and may therefore bridge the eternal tension between the regional and global' (Rip 2001, 4). But because this is not directly and narrowly 'applications-driven, (a) distance is created between the research and its eventual uptake ...' (ibid). Strategic research is thus a 'strategic' synthesis of basic research with the new press to relevance specifically to avoid the 'dominance of short-term considerations' (Rip 2001, 5) - to tap into the money available for social problem solving while preserving a distance from the user interface. Or as Mouton $(2001,26)$ puts it, 'to address the seemingly conflicting demands from internal and external stakeholders'.

Strategic research, with a foot in both basic and applied, is tough-minded research, bringing in the money and advancing knowledge growth. Rip's claim that this now constitutes a new strategic regime of knowledge has considerable merit. It has in turn changed the relation of academia to society in fundamental ways which we are still trying to come to terms with. 


\section{THE HUMANITIES IN PERIL?}

The strategic regime of science doesn't necessarily mean that the academy is out of the woods. Whether it is ruse or reality, there are two key features of this regime that require attention and comment. The first is that it does not suit all disciplines in the same way or to the same degree. The second is that it brings with it a set of potential or actual unintended consequences that might undermine the intellectual enterprise of knowledge and innovation.

To take the difference between the disciplines first. Disciplines, or more properly knowledge structures, differ in two ways. The first way is in terms of what may be called verticality. Verticality has to do with how theory develops. In hierarchical knowledge structures, it develops through integration, towards ever more integrative or general propositions, the trajectory of development of which lends hierarchical knowledge structures a unitary triangular shape. Physics is the paradigm case. Horizontal knowledge structures, on the other hand, are not unitary but plural, consisting of a series of parallel incommensurable languages. Verticality in horizontal knowledge structures occurs not through theory integration but rather through the introduction of a new language which constructs a 'fresh perspective, a new set of questions, a new set of connections, and an apparently new problematic, and most importantly a new set of speakers' (Bernstein 2000, 162). Because these languages are incommensurable, they defy incorporation. The level of integration, and the possibility for knowledge progress in the sense of greater generality and hence explanatory reach, is thus strictly pegged.

This brings me to the second form of knowledge form variation, grammaticality. If verticality has to do with how theory develops internally, with what can be called the internal language of description, grammaticality has to do with how theory deals with the world, or how theoretical statements deal with their empirical predicates, the external language of description. The stronger the grammaticality of a language, the more stably it is able to generate empirical correlates and the more unambiguous because more restricted the field of referents; the weaker it is, the weaker is its capacity to stably identify empirical correlates and the more ambiguous because much broader the field of referents, thus depriving such weak grammar knowledge structures of a principal means of generating progress, namely empirical disconfirmation: 'Weak powers of empirical descriptions removes a crucial resource for either development or rejection of a particular language and so contribute to its stability as a frozen form' (Bernstein 2000, 167-168). In other words, grammaticality determines the capacity of a theory or a language to progress through worldly corroboration; verticality determines the capacity of a theory or language to progress integratively, through explanatory sophistication. Together, we may say that these two criteria determine the capacity a particular knowledge structure has to progress, or to produce 
powerfully integrative new knowledge. The Humanities, by this account, have weak verticality and more ominously, particularly weak grammaticality, the Social Sciences only marginally less so.

Here is the crux of the matter. Under a strategic regime of science, where a robust relation to the world is assumed, knowledge structures of the classical Trivium, that is, the Humanities, which do not possess such a robust relation as we have seen (weak grammaticality), are at a distinct disadvantage. This creates a decided problem for the Humanities and parts of the Social Sciences, including Education. Their raison d'etre, to uphold the value of the inner, is disconnected from the central thrust of the strategic regime and appears to have no purchase on the discourse of strategicality, on the current dominant discourse of 'relevance' and 'development', in a world where the academy's external attunement is of premier importance. Any forthright assertion of its own discourse of inner virtue runs the risk of sounding like weak-minded nostalgia, to be met with impatience or dismissal by the champions of strategicality. Where 'development' so defined is paramount, business as usual for the Humanities is placed in parenthesis, and the only two viable options are sundered from one another, and polarised.

These two options are rendered with spare elegance in John Coetzee's (2004) morality tableau of the two sisters in the chapter on 'The Future of the Humanities in Africa'. Elizabeth Costello, the prize winning novelist sister can be read as representing the classical pole, for whom obtaining 'necessary distance' in a time of strategicality, in a country where the imperatives of strategicality are magnified by history, means accepting that the Humanities are, hopefully temporarily, in eclipse. Sister Blanche, an award winning socially involved nun can be read as representing the opposite pole, for whom 'getting involved' under such circumstances (collapsing all mediating distance) is the only ethical option. Coetzee offers us an unforgettable image of the fate of aesthetic advance under 'responsive' conditions in his depiction of the craftsman's studio filled to the rafters with identically carved icons of the suffering Christ. The imperative is to bring solace to the poverty-stricken parishioners, and to bring in some money to the community. The aim is not artistic advance. A more arresting image of the stalling of Humanities progression in the name of a higher social cause would be hard to imagine.

Of course, tableaux exaggerate matters: they are meant to. Certainly many nimble researchers are able to exploit the margin afforded by the notion of strategic research. Those most responsive to the new regime will seek ingenious ways to apply their discipline, and will succeed. But for many in the Humanities, disciplinarily positioned very far from the user interface, the option will be either to get involved in strategic work - where the money is, and perhaps where the students are - or internal or external disciplinary exile. To the extent that an entire department, or discipline, shifts its attention 'outwards', we can expect some systemic consequences to be a drop in publication of basic research, a lowering number of Ph.D. registrations (too little attention paid to encouraging the new 
intake), possibly problems with supervision (not enough time spent on it), therefore a low number of Ph.D. graduates. If new knowledge and the number of new graduates decline, then so too will the disciplines. On this road, the Humanities are headed for what Jacques Derrida (1994) has called a 'spectral' existence, waiting for history to re-value the virtues of inwardness.

If this sounds unduly pessimistic, it is merely meant to elucidate a possible trend given the analysis above. Two things may militate against it. The first is expressed in the spirit of 'strategic' research as a response to the threat to 'necessary distance'. Otherwise put, academics collectively, if not all academics individually, have proved through the ages to be endlessly inventive and adaptable. Vibrant disciplines and parts of disciplines will survive and prosper, although we may well have to wait first for the pendulum to head back from its present position on the far side of the 'development' imperative. Secondly, and here is a word of advice to the research moguls, it may well be that the most prudent funding strategy, in the meanwhile, is a light touch one which simply continues to fund the best research, and quietly drops the exogenist attempt to 'pull' good scholarship by means of targeted 'thrusts', 'signature themes' and whatnot. These, the analysis above suggests, at present seem to magnify undesirable consequences rather than induce desirable ones. Attempts to shoehorn the Humanities into the discourse of 'development' and 'strategicality' will continue, of course, and we may yet be surprised at what comes to light. But at present, the Humanities are simply unable to match the remarkable fecundity of the hierarchical knowledge structures. Can they chart a third road beyond Elizabeth's option (sitting out the winter of worldliness) and Blanche's option (becoming worldly no matter the cost)? We know what James Bond would have said ....

\section{NOTES}

1. There have been interesting attempts to grapple with the meaning of academic freedom in post apartheid South Africa; see for instance Higgins, 2000 and Du Toit, 2000. Higgs, 2002 provides a measured defence of the university as a 'community of reason' in Habermas' sense.

2. Stix, speaking of Einstein, comments: 'One mark of genius relates to the length of time needed to fully explore, through experimentation, the implications of a new theory' (Stix 2004). The implication here is that the more penetrating the theory, the longer the discovery application lag is.

\section{REFERENCES}

Bernstein, B. 1996. 2000. Pedagogy, symbolic control and identity. Oxford: Rowman \& Littlefield Publishers.

Bawa, A. and J. Mouton. 2002. Research. In Transformation in higher education: Global pressures and local realities in South Africa, eds. N. Cloete et al. Lansdowne: Juta.

Bourdieu, P. 1997. Pascalian meditations. Stanford: Stanford University Press.

Cloete, N. et al. (eds.). 2002. Transformation in higher education: Global pressures and local realities in South Africa. Lansdowne: Juta. 
Cloete, N. and T. Kulati. 2003. Managerialism within a framework of co operative governance. In The higher education managerial revolution. eds. Amaral, A., V. L. Meek and O. Larsen. Amsterdam: Kluwer.

Coetzee, J. 2004. Elizabeth Costello. ( $1^{\text {st }}$ published 2003). London: Vintage.

Department of Education. 1997. Education White Paper 3: A programme for the transformation of higher education. Government Gazette. Pretoria.

. 1997. Higher Education Act of the Republic of South Africa, No 101 of 1997. Pretoria. . 2001. National Plan for Higher Education. Pretoria.

Derrida, J. 1994. Spectres of Marx: The state of the debt, the work of mourning and the new international. London: Routledge.

Durkheim, E. 1977. The evolution of educational thought: Lectures on the formation and development of secondary education in France. Translated by P. Collins. $\left(1^{\text {st }}\right.$ published 1938).London: Routledge \& Kegan Paul.

Delanty, G. 2001. Challenging knowledge: The university in the knowledge society. Buckingham: SRHE/OUP.

Du Toit, 2000. From autonomy to accountability: academic freedom under threat in South Africa? Social Dynamics 26(1):76 133.

Drori, G. S. et al. 2003. Science in the modern world polity: Institutionalisation and globalisation. Stanford: Stanford University Press.

Elias, N. 1987. Involvement and detachment. London: Basil Blackwell.

Ensor, P. 2001. Education programme planning in South Africa: three institutional case studies. In Curriculum restructuring in higher education in post apartheid South Africa, ed. M. Breier. Pretoria: Centre for Science Development.

. 2002. Curriculum. In Transformation in higher education: Global pressures and local realities in South Africa, eds. N. Cloete et. al. Lansdowne: Juta.

.2004. Contesting discourses in higher education curriculum restructuring in South Africa. Higher Education 48:339 359.

Gibbons, M. et al. (eds.). 1994. The new production of knowledge. London, Sage

Glaser, J. 2000. Limits of change: cognitive constraints on 'postmodernization' and the political redirection of science. Social Science Information 39(3):439 465.

Gornitzka, ?. 2003. Science, clients, and the state: A study of scientific knowledge production and use. Enschede: CHEPS/UT.

Gumport, P. 2001. Academic restructuring: organisational change and institutional imperatives. Higher Education 39:67 91.

Gumport, P. and B. Sporn. 1999. Institutional adaptation: demands for management reform and university administration. In Handbook of theory and research. Vol. XIV, eds. Stuart, J. and W. Tierney. New York: Agathon Press.

Higgins, J. 2000. Academic freedom in the new South Africa. Boundary 2(27):97 119.

Higgs, P. 2002. Nation building and the role of the university: a critical reflection. South African Journal of Higher Education 16(2):11 17.

IDRC, see International Development Research Centre.

International Development Research Centre. 1993. Towards a science and technology policy for a democratic South Africa. Montreal: IDRC.

Jansen, J. D. 2004. Accounting for autonomy: how higher education lost its innocence. $41^{\text {st }} \mathrm{T}$. B. Davie Memorial Lecture. University of Cape Town, 26 August 2004.

Lindblom, C. and D. Cohen. 1979. Usable knowledge: Social science and social problem solving. New Haven: Yale University Press. 
Maassen, P. and F. van Vught. 1988. An intriguing Janus head. The two faces of the new governmental strategy for higher education in the Netherlands. European Journal of Education 23:65 76.

. 1989. Dutch higher education in transition. Culemborg: LEMMA.

. 1994. Alternative models of governmental steering in higher education. An analysis of steering models and policy instruments in five countries. In Comparative policy studies in higher education, eds. Goedegebuure, L. and F. van Vught. Utrecht: LEMMA.

Merton, R. 1968. Social theory and social structure. New York: The Free Press.

. 1993. On the shoulders of giants. (1st published 1965).Chicago: The University of Chicago Press.

Mouton, J. 2001. Between adversaries and allies: the call for strategic science in post apartheid South Africa. Stellenbosch: Centre for Interdisciplinary Studies, Stellenbosch University.

Muller, J. and N. Ogude. 2002. Curriculum reform in higher education in South Africa: How academics respond. In Global collaborations: The role of higher education in diverse democracies, ed. E. F. Beckham. Washington DC: Association of American Colleges and Universities.

Muller, J., P. Maassen and N. Cloete. forthcoming 2005. Modes of governance and the limits of policy. In Transformation in higher education: Global pressures and local realities in South Africa, eds. Cloete, N. et al. International edition. Amsterdam: Kluwer.

Muller, J. forthcoming 2005. Responsiveness and innovation in higher education restructuring: the South African case. In Educational restructuring: International perspectives on traveling policies, eds.Popkewitz, T. and S. Lindblad. New York: Information Age Publishing.

National Commission on Higher Education. 1996. A framework for transformation. Pretoria.

Nooteboom, B. 1999. Innovation, learning and industrial organisation. Cambridge Journal of Economics 23:127 150 .

Olsen, J. P. 1988. Administrative reform and theories of organization. In Organizing governance, governing organizations, eds. Campbell, C. and B. G. Peters. Pittsburgh: University of Pittsburgh Press.

Peters, B. G. 2001. The future of governing. (Second edition, revised). Lawrence, KS: University Press of Kansas.

Polanyi, M. 1962. The republic of science. Minerva 1(1):54 73.

Pouris, A. 2003. South Africa's research publication record: the last ten years. South African Journal of Science 99(9/10):425 428.

Redner, H. 1987. The institutionalisation of science: a critical synthesis. Social Epistemology 1(1):37 59 .

Rhoades, G. 2000. Who's doing it right? Strategic activity in public research universities. The Review of Higher Education 24(1):41 66.

Rip, A. 1997. A cognitive approach to relevance of science. Social Science Information 36(4):615 640.

. 2001. Regional innovation systems and the advent of strategic science. Journal of Technology Transfer.

Rip, A. and B. J. R. van der Meulen. 1996. The post modern research system. Science and Public Policy 23:342 352.

Roszack, T. 1968. The dissenting academy. New York: Pantheon Books.

Slaughter, S. and L. Leslie. 1997. Academic capitalism; politics, policies, and the entrepreneurial university. Baltimore: Johns Hopkins University Press. 
Subotzky, G. 1999. Alternatives to the entrepreneurial university: new models of knowledge production in community service programmes. Higher Education 38(4):401 440.

Snow, C. P. 2001. The light and the dark. thirsk: House of stratus. ( $1^{\text {st }}$ published 1947).

Stichcombe, A. No date. Universities and the communism of knowledge as the core of the world information economy. Northwestern University, Mimeo.

Stix, G. 2004. The patent clerk's legacy. Scientific American 23.

Van Vught, F. A. 1991. Autonomy and accountability in government/university relationships. World Bank.

Vattimo, G. 1988. The end of modernity. Baltimore, The Johns Hopkins University Press.

Weingart, P. 1997. From 'finalisation' to 'Mode 2': old wine in new bottles? Social Science Information 36:591 613.

. 1998. Science and the media. Research Policy 27:869 8. 